\title{
ABUNDANTE VIDA \\ A PERSPECTIVA TRANSGRESSORA DO SAGRADO NA OBRA DE VENTURA PROFANA EM DIÁLOGO COM GEORGES BATAILLE
}

Alexandre dos Santos Silva ${ }^{1}$

\section{Resumo}

Este artigo propõe leituras da produção artística de Ventura Profana em interlocução com a obra do pensador francês Georges Bataille, focando no entendimento de ambos sobre os conceitos de "erotismo", "sagrado" e "transgressão". Destaca-se nesse estudo a perspectiva decolonial do pensamento de Ventura, compartilhado através de uma entrevista, na qual as ideias da artista aparecem como um "saber-ruído" (MOMBAÇA, 2013) dissonante às normatividades.

\section{Palavras-chave}

Erotismo. Transgressão. Sagrado. Decolonial. Neopentecostal.

\section{1) Introdução}

Nada é negativo na transgressão.

Foucault, 1963, p. 33

Em 1954, o pensador francês George Bataille, lançou o livro O Erotismo, frequentemente considerado uma de suas publicações mais importantes. Escritor cuja obra se enquadra tanto nos domínios da Literatura como no campo da Antropologia, Filosofia, Sociologia e História da Arte, Bataille aborda em $O$ Erotismo as relações entre aspectos do erótico e do sagrado, a partir do entendimento de ambos como "experiência interior", desenvolvendo conceitos como o "interdito" e a "transgressão".

Bataille propõe o erotismo como uma tentativa de continuidade naquilo que é descontínuo na vida, através de uma erótica que não se submeta à disciplina ou normatizações. Para isso, ele investiga os interditos ligados, por exemplo, à morte, à reprodução, assim como à transgressão - base para o erótico se colocar dialogicamente com o que é profano (ou des-sagrado).

\footnotetext{
${ }^{1}$ Atua como curador independente e pesquisador.Atualmente desenvolve uma pesquisa direcionada à produção artística periférica, colaborando na curadoria de projetos como: "Não precisamos de mitos" Arte Core Festival de Arte Urbana (MAM-Rio), em 2019; e "Cotidiano periférico", no Sesc São João de Metiri - RJ, em 2019.
} 
A sociedade humana não é somente o mundo do trabalho. Simultaneamente - ou sucessivamente - ela é composta pelo mundo profano e pelo mundo sagrado, que são as suas formas complementares. $\mathrm{O}$ mundo profano é dos interditos. $\mathrm{O}$ mundo sagrado abre-se a transgressões limitadas. (BATAILLE, 1954, p.78)

Partindo de pontos estruturantes do pensamento de Bataille, onde a religião e o erotismo, o interdito e a transgressão, o sagrado e o profano, não estão dispostos exatamente em uma bifurcação, proponho neste artigo uma investigação sobre possíveis diálogos (por aproximações ou contrastes) das ideias do filósofo com o trabalho da artista contemporânea brasileira Ventura Profana, que tem como base para sua produção a ressignificação de códigos da cultura cristã-protestante neopentecostal.

$\mathrm{Na}$ formulação deste artigo destaco, sobretudo, a intenção de uma escrita que considere o distanciamento dos contextos temporais, sociais, culturais e políticos sob os quais os pensamentos de Bataille e Ventura se desenvolvem. Diferentemente do filósofo, que mesmo a despeito da radicalidade de suas ideias, tem sua produção circunscrita no contexto da intelectualidade euro-ocidentalizada, a fala subalterna (MOMBAÇA, 2013) de Ventura Profana - jovem artista-travesti (como ela mesma se intitula), negra, nordestina - busca

\begin{abstract}
interrogar o marco do que pode ser ouvido nos termos da cultura euroamericana, colonial, heterocentrada e cisnormativa dominante configura um gesto político-teórico no sentido de uma descolonização, um remapeamento da escuta que leva em consideração o ruído e as linhas-de-fuga que ele fissura na harmonia sobreposta. (MOMBAÇA, 2013)
\end{abstract}

Há nesse artigo, portanto, o desejo de promover ressonância da fala subalternizada (pela perspectiva colonialista) de Ventura, tanto no ambiente acadêmico quanto nas instâncias institucionalizadas das artes. Nesse sentido, este estudo propõe uma ênfase ao "saber-ruído" presente na vida-obra da artista e, simultaneamente, estimula a prática da escuta por parte das instâncias canônicas.

"Quiçá os saberes-ruído, subalternizados por regimes de verdade instaurados pelo cânone acadêmico-científico, não sejam legíveis como saberes, contudo os deslocamentos de que resultam atravessam infecciosamente as tonalidades do conhecimento, perturbando com estridências sem inscrição a escuta canônica" (MOMBAÇA, 2013) 
Para isso, componho o artigo com a transcrição de trechos de uma entrevista feita por mim com a artista. Na conversa, Ventura desenvolve suas ideias sobre arte, erotismo, sagrado e transgressão, contextualizando sua investigação estética, e cumprindo uma função dialógica com os temas desta pesquisa.

Refuto, contudo, estabelecer uma expectativa de legitimação da fala de Ventura Profana pelo ambiente científico-acadêmico. Ao contrário disso, a obra da artista aparece aqui como estridente ruído que busca, desautorizadamente, estremecer e implodir diversos sistemas de normatização. Por isso, a presença do discurso de Ventura numa publicação científica contribui com a descolonização das epistemologias acadêmicas, que historicamente refutam - ou desqualificam - as falas subjetivadas (KILOMBA, 2019, p. 58).

Uma última informação introdutória importante. Este texto foi desenvolvido a partir de recortes específicos de uma investigação mais ampla sobre a influência do movimento neopentecostal na arte contemporânea brasileira. A pesquisa mais abrangente - na qual estou me dedicando à produção de uma dissertação de mestrado busca oferecer novas reflexões acerca da expansão das igrejas evangélicas no país nas últimas décadas e a consequente mudança na configuração social, política e cultural brasileira, a partir da perspectiva sensível e crítica da arte. Para isso, lanço mão da leitura de obras de alguns artistas visuais, de diferentes linguagens, dentre eles, Ventura Profana.

\section{2) A salvação é para todxs}

Ventura Profana é uma jovem artista brasileira, travesti, preta e periférica, que utiliza como principal suporte de trabalho a performance, e tem as redes sociais como fundamental plataforma de divulgação de suas produções. A partir de sua própria vivência em igrejas evangélicas durante a infância e adolescência, a artista desenvolve projetos artísticos que buscam ressignificar os códigos neopentecostais, no sentido da radicalização do amor inclusivo de Jesus Cristo. Para isso, frequentemente, Ventura recorre ao próprio corpo como dispositivo de denúncia e libertação das opressões coloniais vividas como mulher trans racializada.

Nascida em Salvador em 1993 e radicada no Rio de Janeiro, Ventura Profana problematiza os efeitos sociais, culturais e políticos dos processos de tradução e interpretação de textos bíblicos, historicamente apropriados por projetos políticos de 
embranquecimento populacional e concentração de poder. Em alguns trabalhos, realiza interferências visuais sobre imagens, objetos e produtos relacionados ao universo cristão, de modo a questionar a associação entre fé e "neutralização" dos corpos. Em um plano de salvação coletiva, propõe a disputa pela narrativa de Jesus como um corpo dissidente, não hegemônico e não-normativo. Afirmando a si mesma como um corpo apocalíptico, defende a ressignificação e a apropriação do milagre como potência de vida, a abundante vida prometida aos cristãos ${ }^{2}$.

Lançado em 2016, o livro A cor de catu é o primeiro projeto que apresenta assinatura de Ventura Profana. Não é ainda dessa vez, porém, que será atribuída esta alcunha a autoria da obra. O processo de transição de Ventura se consolidou logo após o lançamento da publicação - e o nome que aparece como autoria do livro é de Jackson Boaventura. Apenas as ilustrações e diagramação receberam a assinatura que seria adotada posteriormente pela artista.

A cor de catu é um livro de memórias, onde Ventura Profana compartilha uma coletânea de escritos (em prosa e poesia), ilustrados por desenhos, pinturas e colagens, sobre sua infância na interiorana cidade baiana de Catu. Essa foi uma experiência inaugural da artista autodidata, que começou a desenvolver suas investigações artísticas a partir do interesse pelo design. A publicação, porém, estaria ainda distante da radicalidade adotada por Ventura em seus passos seguintes.

Ainda em 2016, Ventura Profana começa a desenvolver trabalhos que propõem novas abordagens sobre um ambiente que lhe é muito familiar: a cultura neopentecostal. As memórias reaparecem, mas desta vez a partir de um desejo de ruptura com um ciclo de opressão e violência vivenciado pela artista. O processo de rompimento se desenvolve de forma propositiva. Ventura começa então a disputar a narrativa cristã, propondo um Jesus Cristo acolhedor e que se associa aos corpos marginalizados.

As primeiras experiências performáticas de Ventura Profana se desdobram da obra Universal é o reino das bichas (PROFANA, 2017), um objeto artístico constituído por uma calcinha de malha branca estampada com a logomarca da Igreja Universal do Reino de Deus ${ }^{3}$. Ventura então propõe uma releitura do símbolo e inscrições da popular

\footnotetext{
${ }^{2} \mathrm{Na}$ Bíblia, no livro de João, no capítulo 10 e versículo 10, Jesus Cristo diz: “(....) eu vim para que tenham vida; e a tenham em abundância."

${ }^{3}$ A Igreja Universal do Reino de Deus tem sido, desde os anos 1970, protagonista no exponencial crescimento do movimento neopentecostal no Brasil. Sua popularidade se deu, especialmente, pela propagação da "teoria da prosperidade", doutrina religiosa cristã que defende que a bênção financeira é o
} 
igreja ao produzir a estampa com o enunciado transgressor para a comunidade neopentecostal. A universalização das subjetividades em perspectiva da fé, instrumentalizada através da prática missionária das igrejas, é problematizada pelos corpos LGBTQIA+, que têm o acesso ao reino divino negado, com base na condenação da diversidade sexual pelas religiões cristãs. Nesse sentido, o novo slogan também se apresenta como uma louvação à sexualidade das bichas, ou seja, uma exaltação a esses corpos rejeitados pela religião, mas que reivindicam sua religiosidade (ou o direito de se relacionar com o sagrado como bem lhes convém). "Bicha" no discurso de Ventura Profana, é importante ressaltar, não diz respeito apenas a sexualidade dos corpos, mas também se relaciona com performance de gênero e de crítica à cis-heteronormatividade.

A obra Universal é o reino das bichas(2017) traz os elementos estruturantes da pesquisa que Ventura vem desenvolvendo desde então: a releitura de códigos do movimento neopentecostal a partir da concepção de uma sexualidade que vislumbra aceitação e libertação, em contraposição a uma religiosidade que delimita as experiências trangressoras. A pomba do espírito santo inserida no coração vermelho, na obra de Ventura, voa sobre o sexo livre dos corpos dissidentes.

A partir de 2017, Ventura Profana se associa ao produtor musical carioca Jhonatta Vicente e começa a realizar performances artísticas que contam com peças musicais compostas pela dupla. Nasce então $O$ Reino é das bichas ${ }^{4}$. A profanação - ou provocação - se dirigiu ao projeto de moralização do poder político que se instaurou no Rio de Janeiro com a eleição do prefeito Marcelo Crivella, bispo da Igreja Universal do Reino de Deus. Ventura Profana e Jhonatta Vicente ressignificam vestígios de uma educação evangélica, criando um paralelo entre o genocídio da população $\operatorname{TLGBs}^{5}$ e a crucificação de Jesus Cristo.

Em 2017, Ventura produz uma série de colagens digitais, na qual se inclui a obra "BATISMO, um estudo em vermelho" (PROFANA, 2017). O trabalho se estabeleceu

desejo de Deus para os cristãos e que a fé, o discurso positivo e as doações para os ministérios cristãos irão sempre aumentar a riqueza material do fiel. Este argumento é base da análise do livro A ética protestante e o espírito do capitalismo, do pensador alemão Max Weber, lançado em 1904-1905. Segundo estimativas do censo de 2010 realizado pelo Instituto Brasileiro de Geografia e Estatística (IBGE), a IURD tem mais de seis mil templos, doze mil pastores e um milhão e oitocentos mil fiéis ao redor do país. Pelas estimativas próprias, são cerca de oito milhões de seguidores e quinze mil pastores espalhados em cento e cinco países. A enorme abrangência da IURD tem sido conquistada a partir de fortes investimentos em projetos missionários e na administração de empresas de comunicação no Brasil e outros países do mundo.

${ }^{4}$ Um vídeo da perfomance pode ser conferido aqui.

5 Ventura Profana frequentemente subverte a sigla LGBTQ+ (Lésbicas, Gays, Bissexuais e Transexuais/Travestis, Queer); destacando a transexualidade. 
como emblemático, pois trazia a imagem fragmentada do então deputado federal Jair Messias Bolsonaro se batizando de acordo com os preceitos evangélicos. A água batismal, no entanto, é apresentada com coloração avermelhada, representando sangue, devido ao alinhamento do político a grupos extremistas, que evocam ideologias associadas, historicamente, aos eventos de eliminação da diferença através do genocídio. Bolsonaro foi eleito presidente do Brasil no ano seguinte com apoio massivo das igrejas evangélicas.

Em 2018, a artista foi selecionada para a residência artística da $7^{\mathrm{a}}$ edição da Bolsa Pampulha. O projeto desenvolvido por Ventura em Belo Horizonte foi intitulado Tabernáculo da Edificação, um desdobramento de Edyficação, iniciado no ano anterior. O projeto de 2017 consistia no desenvolvimento de uma campanha de financiamento coletivo pra a construção física de uma igreja que pudesse acolher os corpos dissidentes, oferecendo abrigo, assistência social e espiritual a pessoas trans e travestis. A proposta retomada em Belo Horizonte envolveu estudos e redesenhos de mobiliários geralmente encontrados em igrejas neopentecostais, assim como a gravação de um disco. A finalização do projeto se deu em meio à acusação - por parte das artistas participantes da residência - de censura institucional. A performance de Ventura Profana foi inviabilizada, com o fechamento do Museu de Arte da Pampulha, sob alegação oficial da necessidade de reparos estruturais no prédio.

Em outubro de 2019, Ventura lançou o clipe Resplandecente (PROFANA, 2019), no qual interpreta uma canção de sua própria autoria, cheia de referências neopentecostais e da cultura pop, com base musical eletrônica de Jhonatta Vicente. Na letra do hino, Ventura profetiza sua iconoclastia: "Travesti no comando da nação / E nós, juntas rogamos a praga / Que o macho caia / e o seu Deus transicione" (PROFANA, 2019). As imagens do videoclipe foram captadas em Pirapora, município interiorano de Minas Gerais, tendo o rio São Francisco como principal locação. Em maio de 2020 a obra audiovisual já ultrapassava 35.000 visualizações no YouTube.

\section{3) Edificação como a voz de um cu mestiço}

Em 2017, Ventura Profana lançou online uma campanha de financiamento coletivo da primeira proposta do projeto Edyficação. O objetivo era construir um templo em Olaria, subúrbio da Zona Norte do Rio de Janeiro, para acolhimento da população LGBTQ+, onde os membros pudessem preservar sua dignidade, desenvolver seus 
trabalhos e professar a fé em Jesus Cristo (um Cristo que não subjuga os corpos, mas que oferece abundância de vida para a edificação de seres plenos). A campanha não atingiu seu objetivo para arrecadação de recursos e então não se concretizou na materialidade.

"Edi", na linguagem pajubá ${ }^{6}$, significa ânus (ou cu, popularmente). A Edyficação proposta por Ventura sugere uma construção da subjetividade bicha a partir do cu. O ânus está no centro de interesse da libertação dos corpos subalternizados, especialmente no que diz respeito à ruptura com as normatividades hétero-cisgêneras; e também como dispositivo de fala, como atenta Jota Mombaça em seu texto "Pode um cu mestiço falar?"

Duas extremidades de um mesmo tubo, o cu e a boca como órgãos interditados revelam a dimensão corpo-política da construção da realidade. Seguindo ainda as pistas de Kilomba, podemos inferir que, como a interdição da boca dos corpos bio-designados negros estava ligada à constituição de um discurso hegemônico não-negro no contexto da escravidão, a interdição do cu nos corpos adequados à norma heterocissexista torna possível a manutenção do gênero como ideal regulatório atrelado à heterossexualidade como regime político. (MOMBAÇA, 2013)

Sendo o ânus esse ponto de encontro das sexualidades, a Edyficação propõe um reconhecimento das potencialidades comuns aos corpos, das descobertas e principalmente do fortalecimento dos sujeitos sexuais que não limitam seus corpos aos dogmas religiosos. Ou seja, se constituem a partir de uma aceitação do prazer como aspecto positivo e afirmativo da vida.

A temática anal também tem destaque no pensamento de Georges Bataille. Em 1927, Bataille escreveu Ânus Solar, emblemático texto no qual desenvolveu conceitos que partem do seu interesse heterotópico a temas repulsivos à snormatividades. Aparecem em Ânus Solar as expressões "olho pineal" e Jesúvio", como proposições subversivas às funções pré-estabelecidas dos órgãos relacionados à visão e ao excremento, correlacionando-os de outros modos.

De importância fundamental para o pensamento batailliano, o elogio do olho proposto não era uma ode ao órgão responsável pela visão óptica, retiniana-científica, oriunda do positivismo do século XIX e do impressionismo. A sua proposição foi a de um olhar outro porque

${ }^{6} \mathrm{O}$ pajubá (também chamado bajubá) é o socioleto resultante da incorporação do vocabulário de línguas africanas usadas em religiões afro-brasileiras. Inicialmente pratcado como antilinguagem por travestis, foi posteriormente disseminado entre toda a comunidade LGBT e simpatizantes. 
sujo, contaminado, não purista, que não é regido por leis, mas que se forma na inter-relação entre o corpo (ânus e vagina não apenas como orifícios de saída e expulsão de resíduos, mas também de entrada, como maneiras de "ver" e perceber o mundo) e a consciência (interioridade e subjetividade). (PEQUENO, 2014, p. 2)

Os pensamentos contidos em Ânus Solar -publicado apenas em 1931, com ilustrações do surrealista André Masson - encontram ressonância nas elaborações de influentes pensadores posteriores a Bataille, como Antonin Artaud, Gilles Deleuze e Félix Guattari, que desenvolvem o conceito de "corpo sem órgãos"7.

\section{4) A conversa}

Encontrei Ventura Profana em um café na Lapa, no Rio de Janeiro, na manhã de uma terça-feira no final de junho de 2019. Eu havia adiantado a ela por mensagens no WhatsApp que estava desenvolvendo uma pesquisa no âmbito do mestrado, cujo tema trata da influência do movimento neopentecostal na arte contemporânea brasileira. Marcamos essa conversa numa ocasião oportuna da passagem de Ventura pelo Rio (a artista estava na época em residência artística em Belo Horizonte, viabilizada pelo projeto Bolsa Pampulha). Durante um pouco mais de uma hora, Ventura respondeu a algumas questões previamente elaboradas e outras que foram se desencadeando do diálogo. Compartilho abaixo trechos da conversa que nos auxiliam no intento de articulação da obra da artista com os temas do sagrado, erotismo e transgressão:

\section{Queria começar a conversa pedindo que você compartilhasse um pouco de sua} biografia.

Sou Ventura, nasci em Salvador, me criei em Catu. Venho de uma família extremamente cristã, de uma linhagem Batista. Me mudo pro Rio de Janeiro aos 11 anos. E aí no Rio eu comecei a congregar na Igreja Cristã de Nova Vida, em Olaria. Saio da igreja aos 18 anos e dois anos depois eu começo a tecer um trabalho pensando no meu corpo, na beleza do meu corpo, da dissidência, da monstruosidade, me reconhecendo como um corpo trans, um corpo monstro.

\footnotetext{
${ }^{7}$ O conceito de "corpo sem órgãos" (CsO) apareceu, primeiramente, na obra de Antonin Artaud (1974), e foi reativado por Gilles Deleuze e Félix Guattari $(1995$; 1996). Em um sentido bem estrito, trata-se da produção de um corpo mais pleno, mais vivo, mais intenso, um corpo de resistência para o desejo e para a própria vida, o que só é possível se desconstruímos o corpo criado para servir docilmente aos poderes do campo social.
} 


\section{Quando você começou a considerar que o quê você fazia era um trabalho de arte?}

Eu nasci para ser artista. Sempre lutei pra ser. Eu acho que hoje... ou melhor, hoje eu nego esse lugar... quer dizer, acho ótimo ser artista é “muito bem, obrigada!”, mas quero o "aqué" 8 do artista, quero ser paga pelo meu trabalho artístico, quero dinheiro pra produzir, quero ser paga, sei lá, por respirar. Porque, sei lá, o meu corpo é muito sagrado, nesse sentido. Quando eu invado qualquer espaço de arte, eu dou meu nome. E aí é isso: eu acho que só a presença do meu corpo nesse espaço de arte já diz muita coisa. E ele já coloca muita coisa em cheque.

\section{Como o sagrado se manifesta em sua obra?}

$\mathrm{Na}$ manifestação do espírito de vida. Eu acho que meu trabalho todo é fruto de uma tentativa de viver em equilíbrio, em um relacionamento de amor e de temor por um espírito de vida que é poderoso, que me possibilita me santificar. Acho que meu trabalho é um canal. Existem vidas que precisam ser tocadas. Tem uma coisa que se chama evangelho que precisa ser espalhado. E hoje eu sei que eu sou uma missionária, eu tenho uma missão. Eu sou uma travesti evangelista. Eu tenho uma boa nova de vida para espalhar. E eu só consigo estar plena para espalhar essa boa nova porque eu sou movida e sustentada por esse espírito de vida. Então, ele me invade, ele vem de diversas formas. Porque meu trabalho se dá em vários suportes. Eu canto, eu performo, eu sou colagista, eu escrevo, eu agora tenho feito uma linha mais objetual e tal. Então, assim, para que tudo isso aconteça, eu preciso estar conectada com esse espírito de vida. Que eu não acredito que esse espírito seja santo. Se ele for alguma coisa, ele vai ser profano.

\section{Falando em espírito de vida... como a morte aparece no seu trabalho?}

A morte não aparece no meu trabalho! A morte aparece na vida como ela é. A morte ela tá dada. Ela aparece porque ontem uma amiga minha foi morta. Quando a gente tá falando de Brasil, quando a gente tá falando de população trans, de mulher, de preto no Brasil, a gente vai falar de morte. Não tem como. A gente já parte daí, do "vale de ossos secos". Para mim há uma condenação. Eu acho que a gente (travestis) rompe com essa condenação. Existem trabalhos de negação e de luta, assim... Babado! Luta de travesti, batendo na cara da morte e dizendo: “querida, morre antes tu, mas eu não morro!".

8“Aqué” significa dinheiro na linguagem pajubá. . 
Então tem um “fight”. Então é uma condenação porque você já nasce condenado. Preto já nasce condenado. A estrutura conspira, ela está imposta contra nossos corpos como condenação. E isso a bíblia mesmo fala. E aí eu penso que Evangelho é justamente boa nova. Esse é o legado maior da figura de Jesus Cristo. E é por isso que eu sou uma evangelista. Eu tenho trazido uma boa nova de vida para corpos que são condenados pelo mundo.

\section{Como você pratica sua espiritualidade? Você acredita que há em suas obras aspectos espirituais?}

Essa é uma grande questão. Porque o meu trabalho começou a ganhar uma grande responsabilidade. Sei lá, já cantei para mais de 400 pessoas, no palco do Circo Voador, ou num grande teatro em Belo Horizonte, ou numa grande festa de rua em São Paulo. Quando você fala para muita gente, você tem uma grande responsabilidade com a mensagem que você está trazendo. Então, eu não curto me sentir hipócrita. Então eu tive que mudar minha vida por conta desse meu trabalho. Eu tive que... nem sei, assim. Muita coisa precisou ser transformada porque quando você assume o compromisso de falar de vida e tem uma conduta autodestrutiva para mim não funciona, não bate. Porque as pessoas vão ver que não bate. Eu preciso ser testemunho de vida para minhas amigas. Eu quero viver e tenho tecido a minha vida na fé da abundância, na fé da prosperidade, na fé da plenitude de vida, então por isso eu precisei mudar. E aí, sim, quando você faz as coisas guiada por esse espírito de vida, esse espírito de vida se manifesta em você e fala para outras pessoas.

\section{O que significa transgressão para você? Em quais aspectos o seu trabalho artístico pode ser considerado transgressor? Ou o que você almeja transgredir com suas proposições?}

Olha, se a gente for recortando... a gente prega o "gressão" de progressão e mistura com "trans" delas e, daí, transgredir talvez seja esse avanço, na transcendência, no trânsito, na travessia... e aí, eu acho que a gente tá transgredindo desde sempre. A travesti ela é transgressora desde sempre. Mesmo que ela não queira. É uma coisa natural. Eu tenho consciência que para muitos corpos o meu corpo vai ser um corpo transgressor. Mas para mim não. Eu estou só fazendo o mínimo. E eu estou fazendo só porque precisa ser feito. Não porque eu queira chocar ou ser vanguardista. Eu tenho feito porque é necessário. 
Como você acha que o aspecto erótico é desenvolvido em seu trabalho? Quais são as especificidades de se falar sobre o corpo e a sexualidade travesti, no contexto das artes contemporâneas e disputando os códigos neopentecostais?

A religião sempre vai usar o corpo para aquilo que a interessa ou para sacramentar algumas ideias. E o próprio erotismo está dentro da construção da religião, o tempo todo. Mesmo quando a gente vai lá na base católica e na maneira como a fé, o sacrifício é retratado, isso é colocado de maneira erótica. Daí, quando isso é trazido do contexto neopentecostal, as castrações dos corpos se dão de maneira mais violenta. Bem sexista. E os símbolos e os gestos são programados de maneira mais severa. E aí, naturalmente, a resposta a esses tabus, a esses desejos, essas manifestações veladas, elas tendem a ser mais intensas. Eu acho que meu corpo, por ser um corpo travesti, um corpo preto, já é lido de maneira violenta. Já é lido de maneira agressiva. Então, toda vida eu lidei com essa agressividade. E eu sou gigantesca, imensa... Então meu próprio corpo me traz umas "questões de fábrica" para serem resolvidas. E aí, na arte contemporânea, a discussão está partindo muito de “que corpo é esse que tá propondo?”. Então, primeiro, meu corpo é ponto-chave para isso. Para onde eu quero que essa discussão parta? Para mim, eu quero que parta do meu cu. Que parta do maior tabu. Quero que parta da minha bunda. Para mim, partiu da observação disso: de como meu corpo era recebido pelo mundo, de quem despejava o afeto, de onde vinha o "coió", de onde vinha... Isso tudo faz parte de como eu me relaciono com meu trabalho e minha fé.

\section{E quando você começou a associar religião e erotismo em seu trabalho?}

O lugar do trabalho que fica mais sublinhado essa associação de religião e erotismo é na minha escrita. Eu acho que a minha escrita é bastante erótica. Mas, pelo fato de eu ser uma travesti e da travesti estar vinculada à realidade sexual e aos tabus sexuais $(95 \%$ das gatas estão lançadas no campo da prostituição), inevitavelmente você está se relacionando com o sexo, com a objetificação do seu corpo. Então, da mesma maneira que para o homem eu sou um objeto, para a arte eu também sou um objeto. Então eu me assumi artisticamente como um corpo a venda, como uma puta vende seu corpo. Daí é isso, eu assumo os lucros e os prejuízos desse corpo no mercado.

As religiões cristãs têm um papel histórico muito marcante no processo de colonização e aparecem, ainda hoje, como instrumentos de controle e 
normatização dos corpos. Na busca pelas experiências estéticas e místicas do sagrado, por que você decidiu se associar a uma vertente cristã e não se aliou às religiões de resistência, como as de matriz africana, por exemplo?

Porque eu preciso resolver o que me foi dado na minha vida. Tipo assim, para mim (babado!), eu tenho maior admiração do mundo, tenho maior necessidade, pelo axé e, enfim, pela fé preta, mas... Eu, Ventura Profana, preciso resolver questões com o cristianismo. Eu acho que é uma missão. Porque eu preciso me comunicar com minha família. Eu preciso arrancar as vendas dos olhos da minha mãe, do meu pai. Eu preciso salvar minha família de um vírus. E para isso eu só consigo lidando com o veneno. Eu preciso produzir esse antídoto. E eu não consigo produzir esse antídoto com outra substância. Eu preciso recorrer ao veneno que me foi injetado.

\section{5) A experiência estética através do sagrado e do erotismo}

O estímulo para as escolhas das principais referências articuladas nesse artigo os discursos de Georges Bataille e Ventura Profana - está na possibilidade de uma leitura transversal no tempo - e nos contextos sociais e culturais dos autores - sobre as temáticas do sagrado e o erotismo. Bataille e Ventura podem se associar, nesse sentido, em seus pensamentos que buscam a transgressão, evitando as dualidades que estruturam o pensamento cristão-ocidental. Emerge, contudo - e inevitavelmente -, as diferenças nas perspectivas e abordagens do pensador francês e da artista brasileira sobre tais tópicos. Ventura é, em seu tempo, a radicalidade da experiência transgressora quando funde de maneira indissociável seu fazer artístico e sua vivência de mulher trans.

A experiência interior, conceito-chave no pensamento de Bataille, entendido como instância constitutiva do sujeito, é quando abandonamos o mundo profano - o mundo da racionalidade, da utilidade, ou, no sentido foucaultiano, do discurso - ao identificar-nos com o objeto que nos retira da vida descontinua, embora seja o objeto ele mesmo descontínuo. No erotismo, esse objeto é a matéria do desejo, e, na experiência estética, a obra de arte.

Ao relacionar o erotismo e o sagrado com a experiência estética, Bataille rejeita, em certo sentido, parte da tradição do pensamento contemporâneo, contida nas ideias de Friedrich Nietzsche e, posteriormente, Michel Foucault, que frequentemente colocam as experiências ligadas ao sagrado em confronto com os aspectos afirmativos da vida 
humana. Dessa forma, o pensamento de Bataille abre caminho para o da crítica norteamericana Susan Sontag, quando esta afirma que precisamos de uma "erótica da arte", ou seja, uma experimentação extra-intelectual no contato com a arte. Com sua perspectiva heterológica, Georges Bataille busca tocar aquilo que escapa à razão, como uma tentativa de romper com o intelectualismo, racionalismo e cognitivismo.

É desse modo que a proposição batailliana se mostra pertinente para apreensão da produção artística contemporânea. Seu elogio da visão contaminada fornece ao olhar uma apreensão mais corporal, indicando, assim, possibilidades artísticas que extrapolam a noção de forma ou de objeto acabado. Esse olhar outro, então, abarcaria uma produção artística mais processual, e mesmo desmaterializada. (PEQUENO, 2014. p. 9)

Esse movimento de Georges Bataille lembra a constituição da experiência estética proposta por Hans Ulrich Gumbrecht (2006). Para Gumbrecht, o conteúdo arrebatador da experiência estética sempre é produzido a partir da relação entre os efeitos de sentido (conceitos) e os efeitos de presença (percepção). E como consequência imediata, a fusão entre o sujeito e o objeto. A ideia de fusão também aparece na obra de Bataille como direcionamento do erotismo: "O sentido último do erotismo é a fusão" (BATAILLE, 1987, p. 121). É nessa tríade batailliana de experiências (experiência estética, experiência erótica e experiência mística - ou do sagrado) que se apoia a elaboração associativa deste artigo entre o pensamento do filósofo e o da artista Ventura Profana.

Assim como o pensamento de Bataille ofereceu arcabouço teórico para os pósestruturalistas, se posicionando de forma vanguardista na abordagem de vários interditos ligados ao sagrado e ao erotismo, a produção artística de Ventura amplia, no contemporâneo, o repertório de representações do sagrado nas artes visuais, especialmente sobre a temática neopentecostal. Ventura se diferencia da maior parte das abordagens artísticas - e intelectuais - sobre os símbolos evangélicos contemporâneos justamente pelo imbricamento (ou fusão) entre o seu discurso, a vivência e o produto artístico, destacando sua condição de mulher trans, preta, latinoamericana, que reivindica para si a experiência do sagrado.

\footnotetext{
${ }^{9}$ Em seu texto Contra a interpretação, no qual Susan Sontag desenvolve ideias propositivas de contraposição à tradição grega de uma leitura mimética da arte, a crítica norte-americana afirma: "Em vez de uma hermenêutica da arte, precisamos de uma erótica da arte." SONTAG, 1964 p.23
} 
A sobreposição do sensível em relação ao racional que tanto caracteriza as relações religiosas é estrategicamente utilizada no trabalho de Ventura Profana no sentido de introduzir seu discurso evangelizador - e iconoclasta - através do êxtase. Assim como Bataille, a artista propõe uma série de deslocamentos que desprendem o conceito de erotismo do seu lugar de cristalização pedagógica, especialmente quando associado às doutrinas religiosas. O que está em consonância nos discursos de Bataille e Ventura é a busca por essa experiência-limite (ou experiência interior) - no sentido da desnormatização - partindo de uma instância coletiva para uma singularização da experiência transgressora. Ou seja, o estado orgíaco do êxtase no sentido mais radical do erotismo, tensionando vida e morte, unidade e pluralidade, continuidade e descontinuidade, o sagrado e o profano.

É nesta tensão entre supostas dicotomias que se estrutura a potência estética e poética (portanto, política) do trabalho de Ventura Profana. A artista está posicionada na mais radical ruptura com a noção civilizatória dos corpos. Ventura é um corpo estranho em todos os ambientes institucionalizados nos quais possa circular: as igrejas, as instituições de arte, as academias científicas, etc. Seu trabalho se desenvolve na contraposição de um projeto político de poder evangelizador que busca a padronização dos corpos em modelos ortodoxos e repreendidos à diversidade. Projeto este que vem sendo amplamente aderido pela população brasileira, o que culminou com a eleição do presidente Jair Messias Bolsonaro, um político de extrema-direita, com tendências totalitárias, que angariou apoio de grande parte do eleitorado evangélico do país.

\section{6) A perspectiva decolonial na obra de Ventura Profana}

Se os conceitos tratados por Bataille contribuem para uma perspectiva desnormatizante dos corpos, em um sentido mais universalizante - mesmo que destaque a marginalização dos insubmissos -, a obra de Ventura avança no sentido da descolonização desses corpos subalternizados. Há, portanto, especificidades no discurso político da artista que são importantes serem consideradas neste artigo. Recortes que falam sobre um Brasil cristão e extremamente homo/transfóbico ${ }^{10}$.

\footnotetext{
10 O Brasil é o país que mais mata travestis e transexuais em todo o mundo. Esse é o alerta do novo dossiê da Associação Nacional de Travestis e Transexuais (Antra), publicado em 2020, em razão do Dia Nacional da Visibilidade Trans. De acordo com o documento, 124 pessoas trans foram assassinadas em 2019. O México, que está em segundo lugar no ranking global, reportou metade do número de homicídios.
} 
Embora esse artigo não foque nas elaborações acerca da decolonialidade (o tema é abrangente e cheio de nuances, e mereceria uma atenção especial em sua abordagem), é central entendermos o conceito, estruturado e disseminado, principalmente pelos teóricos Walter Mignolo (argentino), Edgardo Lander (venezuelano), Arthuro Escobar (colombiano), Enrique Dussel (argentino), Fernando Coronil (venezuelano), Immanuel Wallerstein (estadunidense), Aníbal Quijano (peruano), através do grupo Modernidade/Colonialidade (1998).

O grupo da modernidade/colonialidade tem encontrado inspiração num amplo número de fontes, desde as teorias críticas europeias e norte-americanas da modernidade, até o grupo sul-asiático dos estudos subalternos, a teoria feminista chicana, a teoria pós-colonial e a filosofia africana; assim mesmo, muitos de seus membros têm operado numa perspectiva modificada de sistemas mundo. Sua principal força orientadora, contudo, é uma reflexão continuada sobre a realidade cultural e política latino-americana, incluindo o conhecimento subalternizado dos grupos explorados e oprimidos (ESCOBAR, 2003 p. 99)

O enunciado de alguns tópicos tratados pelos estudos decoloniais pode nos auxiliar a situar o discurso estético-político de Ventura Profana, e colocá-lo em ressonância com outras(os) pensadoras(es) latinoamericanas(os) contemporâneas(os). O que é, afinal, o ponto de distanciamento entre a artista e o filósofo Georges Bataille.

A assimetria das relações de poder entre a Europa e os territórios colonizados representa uma dimensão constitutiva da noção de modernidade e, portanto, implica necessariamente a subalternização das práticas e subjetividades dos povos dominados. A subalternização da maioria da população mundial se estabelece a partir de dois eixos estruturais baseados no controle do trabalho e no controle da intersubjetividade, o que se desdobra como a designação do eurocentrismo/ocidentalismo como a forma universalizante de produção de conhecimento e subjetividades na modernidade.

A decolonialidade é, em contrapartida, o pensamento que se desloca de uma ideia de mundo estabelecida a partir da perspectiva moderna e capitalista eurocentrada, e se abre para uma diversidade de vozes e caminhos. Trata-se da busca pelo direito à diferença e de uma abertura para um pensamento-outro. $\mathrm{O}$ movimento faz uma intensa crítica à modernidade e à racionalidade, que foram imaginadas, até então, como experiências e produtos exclusivamente europeus. Nesse ponto estão, simultaneamente, o contato e a diferença entre as abordagens de Ventura Profana, artista, mulher, negra, 
trans, latino-americana; e Georges Bataille, filósofo, branco, burguês, europeu. Ventura tem sua produção artística inevitavelmente atravessada pelo trauma colonial, e busca, através do seu trabalho, resgatar a alteridade dos corpos subalternizados que foram - e ainda são - dessubjetivados sistematicamente pelo projeto colonial.

A categoria colonialidade do poder, proposta pelo sociólogo peruano Anibal Quijano, conceitualiza o padrão de dominação global que se constitui como a matriz de poder própria da modernidade. A colonialidade do poder configura-se com a conquista da América, no mesmo processo histórico em que tem início a interconexão mundial (globalidade) e a constituição dos modos de produção capitalista. Esses eventos produzem o surgimento de um sistema inédito de dominação e de exploração, que estruturam um sofisticado sistema de dominação cultural, controlando a produção e a reprodução de subjetividades sob a égide do eurocentrismo e da racionalidade moderna. As religiões cristãs têm sido, historicamente, instrumentos a serviço do iterado processo de colonização de territórios pela Europa, que impõe uma pretensa universalidade, submetida sempre à perspectiva eurocêntrica.

O que está no centro do discurso de Ventura Profana não é apenas a ruptura com a chamada modernidade ocidental, mas a proposição de uma nova modernidade, que parta das especificidades de sua fala, e que esteja comprometida com a superação - ou ressignificação - do trauma colonial. Talvez Ventura esteja mais associada a uma "transmodernidade" (com a pertinência do prefixo), como defende o filósofo Enrique Dussel. A pós-modernidade, segundo Dussel, busca superar as questões negativas da modernidade, mas não quebra seu paradigma da centralidade da Europa. A transmodernidade, por outro lado, denuncia o discurso de totalidade e o encobrimento do outro. $\mathrm{O}$ outro que foi explorado e coisificado e que serviu à razão instrumental do capitalismo enquanto sistema econômico, do liberalismo como sistema político, do eurocentrismo como ideologia, do machismo na erótica, do predomínio da etnia branca no racismo.

A partir do trauma - que Ventura Profana compartilha de maneira elucidativa na conversa que está situada na primeira parte deste artigo -, a artista desenvolve suas pesquisa artística subvertendo a ortodoxia dos códigos neopentecostais. De maneira propositiva, Ventura refunda um evangelho afirmativo de vida (e vida em abundância), desobjetifcando seu corpo e subjetivando sua existência, formulando um novo perfil de congregação, no qual os sujeitos subalternizados, condenados à morte subjetiva e física, 
transgridem essa negação através do sagrado que lhes permite viverem suas singularidades.

Portanto, a proposta afirmativa devida em Ventura Profana muitas vezes se manifesta em forma de negação à morte. Esse aparente paradoxo se justifica pelo fato de que corpos dissidentes como o da artista - marcados pela experiência colonizadora são acometidos não apenas pela supressão de suas subjetividades, mas também pelo extermínio físico. Ou seja, estão historicamente em perspectiva negativa. É preciso primeiramente rejeitar essa anulação destinada aos subalternizados para então se afirmar como sujeitos plenos. Nesse limite tênue, onde se distingue o antídoto do veneno(citando como referência a própria fala da artista, compartilhada na entrevista acima), que se desenvolve o trabalho de Ventura. A partir da apropriação dos códigos evangelicistas, a artista refunda um evangelho - iconoclasta e desnormatizante - onde o sagrado e profano podem se manifestar através das experiências interiores. Desta forma, Ventura não apenas atualiza as abordagens literárias de Bataille sobre erotismo e sagrado, mas, sobretudo, transgride a perspectiva sobre esses tópicos, através de sua postura performática que funde vivência e fazer artístico.

\section{Referências}

ANTRA. Boletim 1/2020: ASSASSINATOS contra TRAVESTIS e TRANSEXUAIS brasileiras. Associação Nacional de Travestis e Transexuais, 2020. Disponível em: https://antrabrasil.files.wordpress.com/2020/05/boletim-1-2020-assassinatos-antra.pdf.

BATAILLE, Georges. O ânus solar. Lisboa: Hiena Editora, 1985.

O erotismo. Porto Alegre: L\&PM, 1987.

A experiência interior. São Paulo: Editora Ática, 1992.

BOAVENTURA, Jackson. A cor de catu. Belo Horizonte: Oi Kabum!, 2016.

DELEUZE, Gilles; GUATTARI, Félix. O anti-Édipo - Capitalismo e esquizofrenia. Lisboa: Assírio \& Alvim, 2004.

DUSSEL, Enrique. Para una ética de la liberación latinoamericana - v. I-II. Buenos Aires: Siglo Veintiuno Editores, 1973.

ESCOBAR, Arturo. Mundos y conocimientos de outro modo: el programa de investigación de modernidad/colonialidade latinoamericano. Tabula Rasa, $n^{\circ} 1$ Ene.Dic. 2003. 
FOUCAULT, Michel. Prefácio à transgressão. Estética - Literatura e Pintura, Música e Cinema - Col. Ditos \& Escritos III, 2015.

GUMBRECHT, H.U. Corpo e forma: ensaios para uma crítica não hermenêutica. Rio de Janeiro, EdUERJ, 1998.

MOMBAÇA, Jota. Pode um cu mestiço falar? Medium, 2015. Disponível em:https://medium.com/@jotamombaca/pode-um-cu-mestico-falar-e915ed9c61ee.

PEQUENO, Fernanda. Georges Bataille, o olho e a economia: a arte como despesa improdutiva. Concinnitas, 2014. Disponível em:https://www.epublicacoes.uerj.br/index.php/concinnitas/article/view/18709.

PROFANA, Ventura. BATISMO, um estudo em vermelho. 2017.

. Universal é o reino das bichas. 2017.

Tabernáculo da edificação. 2018.

PROFANA, Ventura; VICENTE, Jhonatta. Edyficação. 2017.

O reino é das bichas. 2017.

Resplandescente. 2019.

QUIJANO, Anibal. Colonialidade do poder, eurocentrismo e América Latina. In: LANDER, Edgardo (Org.). A colonialidade do saber: eurocentrismo e ciências sociais. Buenos Aires: Clacso, 2005.p. 227-278.

SONTAG, Susan. Contra a Interpretação. Trad. Ana Maria Capovilla. Porto Alegre: L\&PM, 1987.

WEBER, Max A ética protestante e o espírito do capitalismo. São Paulo: Cengage Learning, 2009.

\author{
ABUNDANT LIFE \\ THE AFFIRMATIVE PERSPECTIVE OF THE HOLY IN THE ART OF VENTURA \\ PROFANA IN DIALOGUE WITH GEORGES BATAILLE
}

\begin{abstract}
This article proposes a reading of the artistic production of Ventura Profana in dialogue with the work of the French literary figure Georges Bataille, focusing on the understanding of both on the concepts of "eroticism", "holy" and "transgression". In this research, the decolonial perspective of Ventura's thought stands out, shared through an interview, in which the ideas appear as a "knowledge-noise" (MOMBAÇA, 2013) dissonant to normative notions.
\end{abstract}




\section{Keywords}

Eroticism. Transgression. Sacred. Decolonial. Neopentecostal. 